\title{
"Battery of Bioassays" for Diagnostics of Toxicity of Natural Water when Pollution with Aluminum Compounds
}

\author{
Anna Olkova ${ }^{1 *}$, Grigory Berezin ${ }^{1}$ \\ 1 Department of Ecology and Nature Management, Institute of Chemistry and Ecology, Vyatka State University, \\ Krasnoarmeyskaya Str. 26, Kirov, 610001, Kirov region, Russia \\ * Corresponding author's e-mail: morgan-abend@mail.ru
}

\begin{abstract}
The article presents the results of an experimental comparison of the sensitivity of biotests using Daphnia magna Straus, Ceriodaphnia affinis Lilljeborg, Paramecium caudatum Ehrenberg, and Escherichia coli Migula (strain M-17) to water pollution with aluminum compounds. The research was carried out under simulated conditions: the model toxicant was aluminum sulfate $\mathrm{Al}_{2}\left(\mathrm{SO}_{4}\right)_{3} \cdot 18 \mathrm{H}_{2} \mathrm{O}$, the concentration range per $\mathrm{Al}$ was $0.04-2.8 \mathrm{mg} / \mathrm{dm}^{3}$, and the $\mathrm{pH}$ of the tested waters was close to the neutral level of 7.2-7.8. The bioluminescence of E. coli significantly decreased at an $\mathrm{Al}$ concentration of $0.8 \mathrm{mg} / \mathrm{dm}^{3}$ (toxicity index was $93.3 \pm 1.2$, which refers to a high level of toxicity). The reaction of $P$. caudatum was weaker: a high level of toxicity was achieved at an Al concentration of $2.8 \mathrm{mg} / \mathrm{dm}^{3}$. These doses did not cause the death of D. magna and C. affinis in short-term experiments (28 and 96 hours, respectively). However, in the tests for the chronic toxicity of aluminum, we showed that the doses of 0.8 and $2 \mathrm{mg} / \mathrm{dm}^{3} \mathrm{Al}$ cause high death of individuals (more than 50\%) and a significant decrease in the number of offspring. The range of sensitivity of the bioassay methods to water pollution with aluminum turned out to be as follows: bioassay for the bioluminescence of $E$. coli $>$ bioassay for the changes in chemotaxis of $P$. caudatum $>$ bioassay for the changes in fertility of D. magna $>$ bioassay for the changes in fertility of $C$ affinis.
\end{abstract}

Keywords: bioassay, aluminum, battery of bioassays, Daphnia magna, Ceriodaphnia affinis, Paramecium caudatum, Escherichia coli.

\section{INTRODUCTION}

Aluminum is one of the most abundant elements in the Earth's crust, it is found in macroquantities in natural water, bottom sediments, solid phase soil and soil solution. This element enters natural waters both naturally with partial dissolution of clays and aluminosilicates, and as part of industrial emissions. Aluminum salts are also widely used as coagulants in municipal water treatment processes. Aluminum compounds are included in vaccines. Recently, engineered nanomaterials of aluminum have begun entering the environment [Santos and Vieira 2017; Ochoa at al. 2018]. These facts prove the relevance of studying the effect of aluminum compounds on living organisms.

It is known that most aluminum compounds are hardly soluble in water; therefore, they have low bioavailability for biota. However, the intake of aluminum into the body, even in low doses, is dangerous for people. The work [Dorea 2020] shows the dependence of neurological diseases of infants on the intake of aluminum contained in vaccines and infant formula. In the work [Chen 2020] the mechanisms of aluminum neurotoxicity were revealed using the example of Danio fish: aluminum accumulates in the brain tissues, which leads to progressive impaired neurodevelopmental behaviors as well as latent learning and memory performance.

In the work [Poganyova, Kerekes and Micieta 2017], the aluminum smelter and its emissions were presented as an ecogenotoxic factor. Other works confirmed this: aluminum ions and its compounds are genotoxic both in vitro and in vivo [Lima et al. 2007; Lankoff et al. 2006]. 
The authors of the work [Arnolds, Snyman and Odendaal 2018], using the example of the Ceratophyllum demersum L. macrophyte, showed that aluminum can accumulate in biological tissues; the comparative series of bioaccumulation is as follows: $\mathrm{Zn}>\mathrm{Al}>\mathrm{Cu}$.

These specialized studies confirm that aluminum compounds contribute to the integral toxicity of natural environments, although they are hardly soluble at neutral $\mathrm{pH}$ level. Near the enterprises for the extraction of aluminosilicates and aluminum smelters, aluminum compounds are becoming a priority type of environmental pollution. Ecological monitoring of such areas usually includes classical ecotoxicological tests using the bioassay protocols approved at the state level. The purpose of the study was to compare the sensitivity of the biotests for the mortality and fertility of Daphnia magna Straus and Ceriodaphnia affinis Lilljeborg experimentally, as well as the express biotests for the pre-lethal reactions of Paramecium caudatum and Escherichia coli (strain M-17) to the pollution of natural waters with aluminum compounds.

\section{MATERIAL AND METHODS}

In order to achieve the goal, model experiments were carried out. Aluminum sulfate $\mathrm{Al}_{2}\left(\mathrm{SO}_{4}\right)_{3} \cdot 18 \mathrm{H}_{2} \mathrm{O}$ was added in various concentrations into the natural water sampled from an underground well. Sulfate anions are natural components of most natural waters; therefore, the toxic effect of additives manifested itself due to aluminum and its water-soluble forms. The Russian environmental standard for the content of aluminum in reservoirs for fishery purposes is $0.04 \mathrm{mg} / \mathrm{dm}^{3}$.

Laboratory parthenogenetic aquacultures of Daphnia magna and Ceriodaphnia affinis were used. Juvenile crustaceans at the age of 6-24 hours were used for bioassay, which were obtained in synchronized cultures of the same age. An indicator of acute toxic effects was a significant decrease in the motor activity of crustaceans in comparison with the control variants [Olkova and Zimonina 2020], as well as the death of experimental individuals. The indicator of chronic toxic effects was a significant decrease in the fertility of individuals in the experimental variants of the tested waters, as compared with the control medium [Federal Register FR 1.39.2007.03222 2007]. The control was natural underground water, which is suitable chemically for daphnia.

In the express biotests, the intensity of bioluminescence of the bacterial suspension of Escherichia coli was determined with the help of the Biotox device (Russia) [Environmental Regulatory Document PND F T 14.1:2:3:4.11-04. T.16.1:2:3:3.8-04. 2010], whereas the degree of inhibition of the chemotactic reaction of the Paramecium caudatum ciliates was determined with the help of the Biotester-M device (Russia) [Federal Register FR 1.39.2015.19242 2015].

During the chemical analysis of this water, no aluminum ions were found in its composition (in the measurement range from 0.04 to $0.56 \mathrm{mg} / \mathrm{l}$ ). The $\mathrm{pH}$ level of the tested waters was in the range optimal for crustaceans (7.2-7.8).

\section{RESULTS}

\section{Express bioassay using protozoa and bacteria}

The effect of aluminum (aluminum sulfate addition) on microorganisms in the biotests based on the responses of $P$. caudatum and E. coli was compared (Table 1). The range of tested Al concentrations in this series of experiments was from $0.04 \mathrm{mg} / \mathrm{dm}^{3}$ to $2.8 \mathrm{mg} / \mathrm{dm}^{3}$ (calculation of the content of a chemical element in the additive).

An increase in the concentration of aluminum salt in the solution led to a proportional increase in water toxicity in terms of inhibition of chemotaxis in P. caudatum ciliates. The effect was observed even with the addition of salt corresponding to 1 MPC $\left(0.04 \mathrm{mg} / \mathrm{dm}^{3}\right)$ : the toxicity index of this sample was 1.4 times higher than the control value. A further increase in the dose in the range from 0.08 to $2.0 \mathrm{mg} / \mathrm{dm}^{3}$ led to an increase in the level of toxicity up to group II (medium toxicity) in accordance with the method used [Federal Register FR 1.39.2015.19242 2015]. A high level of toxicity for ciliates was achieved with the addition of aluminum equal to $2.8 \mathrm{mg} / \mathrm{dm}^{3}$.

For E. coli, the dynamics of the increase in the effects in response to an increase in the concentration of aluminum sulfate in the tested water was different. At an aluminum concentration in water of 0.04 and $0.08 \mathrm{mg} / \mathrm{dm}^{3}$, an inhibition of bacterial bioluminescence was not observed. Aluminum additions at a level of $0.8 \mathrm{mg} / \mathrm{dm}^{3}$ and above caused a sharp increase in the toxicity index, which was close to the maximum possible inhibition of the test function of bacteria. 
Table 1. Results of the express biotests of natural water with aluminum sulfate additives

\begin{tabular}{|c|c|c|c|}
\hline \multicolumn{2}{|c|}{ Experimental variant } & \multicolumn{2}{|c|}{$\begin{array}{c}\text { Biotesting result, toxicity index, } \\
\text { conventional units }\end{array}$} \\
\hline $\begin{array}{c}\mathrm{Al}^{*} \text { additive, } \\
\mathrm{mg} / \mathrm{dm}^{3}\end{array}$ & $\begin{array}{c}\text { MPC } \\
\text { frequency }\end{array}$ & P. caudatum & E. coli \\
\hline 0 & 0 & $0.24 \pm 0.01$ & 0 \\
\hline 0.04 & 1 & $0.35 \pm 0.03$ & 0 \\
\hline 0.08 & 2 & $0.49 \pm 0.05$ & 0 \\
\hline 0.8 & 20 & $0.40 \pm 0.03$ & $93.3 \pm 1.2$ \\
\hline 1.2 & 30 & $0.61 \pm 0.09$ & $95.6 \pm 2.4$ \\
\hline 2 & 50 & $0.69 \pm 0.08$ & $96.1 \pm 2.9$ \\
\hline 2.8 & 70 & $0.73 \pm 0.10$ & $96.2 \pm 3.4$ \\
\hline
\end{tabular}

Note: * Aluminum sulfate was added, the final content of the element $\mathrm{Al}$ in the tested medium was taken into account in the calculations. The values corresponding to toxicity group II (average toxicity) are shown in bold. The values corresponding to the III toxicity group (high toxicity level) are shown in bold and italics.

Comparing the obtained data, the following conclusion was made: the bioluminescent test using E. coli was more sensitive to the presence of aluminum in water than the express biotest based on the chemotaxis of $P$. caudatum.

\section{Determination of chronic toxicity of aluminum for lower crustaceans}

In preliminary tests, the concentration of aluminum in the aquatic environment was determined, which did not cause the death of crustaceans during the acute experiment (96 hours for D. magna and 48 hours for C. affinis). Next, model solutions were tested, in which D. magna and C. affinis could live and reproduce offspring for 25 or more days (Table 2 ).

The investigated model solutions did not cause the death of D. magna and C. affinis during the periods of determination of acute toxicity. However, observations of experimental organisms for 25 days showed that the doses of aluminum equal to 0.8 and $2 \mathrm{mg} / \mathrm{dm}^{3}$ lead to a gradual decrease in the number of crustaceans in the samples (death over 50\% in all variants at the end of the experiment), and also cause significant inhibition fertility of crustaceans compared with control indicators. The fecundity of D. magna was inhibited by 3 times, compared with the indicator in pure water, and C. affinis, on average, 2 times. The death rate of D. magna was, on average, $10 \%$ higher than that of $C$. affinis. Consequently, D. magna was found to be more sensitive to aluminum contamination than $C$. affinis.

It must be noted that the effects of the two tested doses did not differ significantly and this can be seen both from the results of experiments with D. magna and C. affinis.

\section{DISCUSSION}

In natural waters, aluminum is present in ionic, colloidal and suspended forms. The element has a low migration ability. It forms rather stable complexes, including organomineral ones, which are in water in a dissolved or colloidal state [Tyantova et al. 2005]. However, these physicochemical properties of aluminum cannot completely neutralize its negative effect on aquatic organisms. The information on the effect of aluminum on biota representatives continues to grow. It has recently been shown that aluminum at a concentration of 0.2 to $0.6 \mathrm{mM}$ at $\mathrm{pH} 7.5$ significantly reduces the amount of protein, chlorophyll, mycosporine-like amino acids, phycobiliproteins, extracellular and intracellular macronutrients such as phosphate and nitrate contents, and nitrate reductase activity in cyanobacterium Nostoc sp. strain HKAR-2 [Kannaujiya et al. 2020].

It is known that the "battery of biotests" includes at least three biological species [Pandard et al. 2006; Zovko et al. 2015]. According to the principle of a "battery of biotests" the sensitivity

Table 2. Comparison of the sensitivity of D. magna and C. affinis to aluminum sulfate

\begin{tabular}{|c|c|c|c|}
\hline \multirow{2}{*}{$\begin{array}{c}\text { Al content in the test } \\
\text { medium }\end{array}$} & \multicolumn{2}{|c|}{$\begin{array}{c}\text { Fertility for 25 days, } \\
\text { individuals/a female }\end{array}$} & \multicolumn{2}{c|}{$\begin{array}{c}\text { Mortality on the 25th day of the } \\
\text { experiment, } \%\end{array}$} \\
\cline { 2 - 4 } & D. magna & C. affinis & D. magna \\
\hline $\begin{array}{c}\text { C affinis } \\
\text { (Control) }\end{array}$ & $15 \pm 0.9$ & $38.6 \pm 11.3$ & 0 \\
\hline $\begin{array}{c}0,8 \mathrm{mg} / \mathrm{dm}^{3} \\
20 \mathrm{MPC}\end{array}$ & $4.6 \pm 1.0^{*}$ & $18.7 \pm 9.5^{*}$ & $66 \pm 3$ \\
\hline $\begin{array}{c}2 \mathrm{mg} / \mathrm{dm}^{3} \\
50 \mathrm{MPC}\end{array}$ & $5.1 \pm 2.3^{*}$ & $16.0 \pm 9.7^{*}$ & $69.3 \pm 5.1$ \\
\hline
\end{tabular}

Note: The values significantly differ from the control values according to the Student's criterion. 
of four biotesting methods to water contamination with aluminum were tested. The $P$. caudatum and E. coli microorganisms were found to be more sensitive to aluminum pollution of the aquatic environment in comparison with the lower crustaceans D. magna and C. affinis. This can be explained by the biological characteristics of crustaceans. Multicellularity, chitinous cover, periodic molting help to reduce the toxic load [Animal Models in Toxicology 2016]. Despite the prevalence of complex aluminum compounds over its truly dissolved forms, long-term chronic trials have shown the negative effects of aluminum sulfate for multicellular hydrobionts: delayed death and decreased fertility.

The organisms used in the "battery of biotests" turned out to be highly sensitive in comparison with the data of other scientific works. For example, in [Cardwell et al. 2018], the 10\% effect concentrations (EC10s) ranged from $98 \mathrm{mg}$ total $\mathrm{Al} / \mathrm{L}$ for $D$. rerio to $2175 \mathrm{mg}$ total $\mathrm{Al} / \mathrm{L}$ for $L$. minor. In our work, the effective doses of $\mathrm{Al}$ for $P$. caudatum were at the level of $0.04 \mathrm{mg} / \mathrm{L}$ and higher, and chronic effects for Daphnia were observed at $0.8 \mathrm{mg} / \mathrm{LAl}$. The $\mathrm{pH}$ level, which has a high value for the manifestation of aluminum toxicity, was comparable.

\section{CONCLUSIONS}

Aluminum compounds have a negative effect on aquatic organisms not only during acidification of water, but also at a neutral $\mathrm{pH}$ level. Toxic effects for most of the experimental organisms in our work (Daphnia magna, Ceriodaphnia affinis, Escherichia coli) were observed at an aluminum concentration of $0.8 \mathrm{mg} / \mathrm{dm}^{3}$ and higher. The Paramecium caudatum ciliates responded to the aluminum doses of $0.08 \mathrm{mg} / \mathrm{dm}^{3}$.

The comparative series of sensitivity of the bioassay methods was as follows: bioassay for the $E$. coli bioluminescence $>$ bioassay for the changes in chemotaxis in $P$. caudatum $>$ bioassay for the changes in fertility of $D$. magna $>$ bioassay for the changes in fertility of C. affinis.

We recommend using the express biotests with $P$. caudatum and E. coli to diagnose "burst" discharges of aluminum compounds into natural waters. The experiments to determine the chronic toxic effect of samples using different species of daphnia will serve for a more detailed study of the properties of the tested media and will help to predict the consequences of anthropogenic pollution of real ecosystems.

\section{REFERENCES}

1. Gad S.C. (Ed.) 2016. Animal Models in Toxicology. by . 3rd ed. Boca Raton, FL: CRC Press, 1152 p..

2. Arnolds, J.L., Snyman, R.G., Odendaal, J.Ph. 2018. Bioaccumulation of $\mathrm{Al}, \mathrm{Cu}$ and $\mathrm{Zn}$ in Coontail (Ceratophyllum demersum L.) after experimental exposure to a metal cocktail "pollution event". Fresenius Environmental Bulletin, 27(2), 928-937.

3. Cardwell, A.S., Adams, W.J., Gensemer, R.W., Nordheim, E., Santore, R.C., Ryan, A.C., Stubblefield, W.A. 2018. Chronic Toxicity of Aluminum, at a $\mathrm{pH}$ of 6, to Freshwater Organisms: Empirical Data for the Development of International Regulatory Standards/Criteria. Environmental Toxicology and Chemistry, 37(1), 36-48, DOI: 10.1002/etc.3901

4. Chen, J., Fan, R., Wang, Y.H., Huang, T., Shang, N., He, K.H., Zhang, P., Zhang, L., Niu, Q., Zhang, Q.L. 2020. Progressive impairment of learning and memory in adult zebrafish treated by $\mathrm{Al} 2 \mathrm{O} 3$ nanoparticles when in embryos. Chemosphere, 254, 126608, DOI: 10.1016/j.chemosphere.2020.126608

5. Dorea, J.G. 2020. Neurotoxic effects of combined exposures to aluminum and mercury in early life (infancy). Environmental Research, 188, 109734, DOI: 10.1016/j.envres.2020.109734

6. Environmental Regulatory Document PND F T 14.1:2:3:4.11-04. T.16.1:2:3:3.8-04. 2010. Method for determining the integrated toxicity of surface waters, including marine, ground, drinking, waste waters, water extracts from soils, waste, sewage sludge by changes in bacterial bioluminescence using the "Ecolum test-system". Moscow: Nera-S, 30 p.

7. Federal Register FR 1.39.2007.03222. 2007. Methodology for determining the toxicity of water and water extracts from soils, sewage sludge, and waste by mortality and changes in fertility of daphnias. Moscow: Akvaros, $51 \mathrm{p}$.

8. Federal Register FR 1.39.2015.19242. 2015. Environmental Regulatory Document PND F T 16.2:2.2-98. Methodology for determining the toxicity of samples of natural, drinking, domestic and drinking, household waste, treated sewage, waste, thawed, technological water by the express method using the Biotester device. St. Petersburg: SPEKTR-M, $21 \mathrm{p}$.

9. Kannaujiya, V.K., Kumar, D., Pathak, J., Rajneesh, Sinha, R.P. 2020. Physiological and Biochemical Response of a Hot-Spring CyanobacteriumNostocSp. Strain HKAR-2 to Aluminum Toxicity. Water Air and Soil Pollution, 231(7), 359, DOI: 10.1007/ s11270-020-04739-Z

10. Lankoff, A., Banasik, A., Duma, A., Ochniak, E., Lisowska, H., Kuszewski, T., Góźdź, S. and Wojcik, A. 2006. A comet assay study reveals that aluminium induces DNA damage and inhibits the repair of 
radiation-induced lesions in human peripheral blood lymphocytes. Toxicol. Lett., 161, 27-36.

11. Lima, P.D.L., Leite, D.S., Vasconcellos, M.C., Cavalcanti, B.C., Santos, R.A., Costa-Lotufo, L.V., Pessoa, C., Moraes, M.O. and Burbano, R.R. 2007. Genotoxic effects of aluminium chloride in cultured human lymphocytes treated in different phases of cell cycle. Food Chem. Toxicol., 45, 1154-1159.

12. Ochoa, L., Zuverza-Mena, N., Medina-Velo, I.A., Flores-Margez, J.P., Peralta-Videa, J.R., GardeaTorresdey, J.L. 2018. Copper oxide nanoparticles and bulk copper oxide, combined with indole-3-acetic acid, alter aluminum, boron, and iron in Pisum sativum seeds. Science of the Total Environment, 634, 1238-1245, DOI: 10.1016/j.scitotenv.2018.04.003

13. Olkova, A. Zimonina, N. 2020. Assessment of the toxicity of the natural and technogenic environment for motor activity of Daphnia magna. Journal of Ecological Engineering, 21(7), 11-16, DOI: $10.12911 / 22998993 / 125459$

14. Pandard, P., Devillers, J., Charissou, A.M., Poulsen,
V. 2006. Selecting a battery of bioassays for ecotoxicological characterization of wastes. Science of the Total Environment, 363, 114-125.

15. Poganyova, A., Kerekes, E., Micieta, K. 2017. The ecogenotoxic plant biomonitoring of a long-term polluted area in central Slovakia. Environmental Science and Pollution Research, 24(35), 27376-27383, DEC DOI: $10.1007 / \mathrm{s} 11356-017-0353-\mathrm{z}$

16. Santos, R.J., Vieira, M.T. 2017. Assessment of airborne nanoparticles present in industry of aluminum surface treatments. Journal of Occupational and Environmental Hygiene, 14(3), D29-D36, DOI: 10.10 80/15459624.2016.1254782

17. Tyantova E.N., Burukhin S.B., Synzynys B.I., Kozmin G.V. 2005. The chemistry of Aluminum in the environment. Agrochemistry, 2, 87-93.

18. Zovko, M., Vidaković-Cifrek, Ž., Cvetković, Ž., Bošnir, J. 2015. Assessment of acrylamide toxicity using a battery of standardised bioassays. Archives of Industrial Hygiene and Toxicology, 66, 315-321. DOI 10.1515/aiht-2015-66-2715 